\title{
Incarcerating juveniles in adult prisons as a factor in depression
}

IRENE Y.H. NG ${ }^{1}$, XIAOYI SHEN ${ }^{1}$, HELEN SIM ${ }^{1}$, ROSEMARY C. SARRI ${ }^{2}$, ELIZABETH STOFFREGEN ${ }^{2}$ AND JEFFREY J. SHOOK ${ }^{3}$, ${ }^{1}$ Department of Social Work, National University of Singapore, Singapore; ${ }^{2}$ Center for Political Studies, Institute for Social Research, University of Michigan, Ann Arbor, MI, USA; ${ }^{3}$ School of Social Work, University of Pittsburgh, Pittsburgh, PA, USA

\section{ABSTRACT}

Background While existing research has shown higher prevalence of depression among incarcerated youths compared with non-incarcerated youths, none has studied incarceration as a cause of depression.

Aims/hypothesis This study suggests that incarceration, in particular placement of youths in adult incarceration, is a factor in developing depression.

Method A records based comparison of depression among youths in different types of incarceration with non-incarcerated youths, controlling for other predictors of depression, namely offence type, family poverty, parents' history of incarceration and demographic profile.

Results Youths in adult placements were significantly more likely to be depressed than youths in juvenile placements and community-based youths.

Conclusion and implications The findings suggest that there are mental health implications against incarcerating youths in adult prisons, a concern that current juvenile justice might not have considered adequately. Copyright (c) 2010 John Wiley $\mathcal{B}$ Sons, Ltd.

\section{Introduction}

Several studies have shown that incarcerated youths experience higher rates of depression than non-incarcerated youths (Grisso et al., 2005). Table 1 shows that rates of depression of varying severity among inmates range from $5 \%$ (Boothby and Durhma, 1999) to 61\% (Domalanta et al., 2003).

In their assessment of the Beck Depression Inventory for screening inmates, Boothby and Durham (1999) justified the need for screening even though 'many 
Table 1: Depression among incarcerated population

\begin{tabular}{|c|c|c|c|c|c|}
\hline No. & Source & $\begin{array}{l}\text { Depression } \\
\text { Measure }\end{array}$ & Population & $N$ & $\begin{array}{l}\text { Depression } \\
\text { Rate (\%) }\end{array}$ \\
\hline \multirow[t]{2}{*}{1} & \multirow[t]{2}{*}{$\begin{array}{l}\text { Washburn et al. } \\
\text { (2008) }\end{array}$} & \multirow[t]{2}{*}{$\begin{array}{l}\text { Major Depression } \\
\text { (based on DSM } \\
\text { III-R) }\end{array}$} & $\begin{array}{l}\text { Arrested and detained } \\
\text { youths processed in } \\
\text { adult court }\end{array}$ & 275 & 16.0 \\
\hline & & & $\begin{array}{l}\text { Arrested and detained } \\
\text { youths processed in } \\
\text { juvenile court }\end{array}$ & 1440 & 14.0 \\
\hline 2 & $\begin{array}{l}\text { Wasserman et al. } \\
\text { (2004) }\end{array}$ & $\begin{array}{l}\text { Major Depression } \\
\text { (based on DSM } \\
\text { III-R and } \\
\text { DSM-IV and } \\
\text { WHO's ICD-10) }\end{array}$ & $\begin{array}{l}\text { Youths in the juvenile } \\
\text { justice system }\end{array}$ & 296 & 7.2 \\
\hline \multirow[t]{7}{*}{3} & \multirow{7}{*}{$\begin{array}{l}\text { Domalanta et al. } \\
\text { (2003) }\end{array}$} & \multirow{7}{*}{$\begin{array}{l}\text { Mild/ Moderate } \\
\text { or Severe } \\
\text { Depression (Beck } \\
\text { Depression } \\
\text { Inventory) }\end{array}$} & Detained male (mild) & 750 & 22.5 \\
\hline & & & Detained female (mild) & 274 & 20.1 \\
\hline & & & $\begin{array}{l}\text { Detained male } \\
\text { (moderate) }\end{array}$ & 750 & 24.8 \\
\hline & & & $\begin{array}{l}\text { Detained female } \\
\text { (moderate) }\end{array}$ & 274 & 27.4 \\
\hline & & & Detained male (severe) & 750 & 20.0 \\
\hline & & & Detained female (severe) & 274 & 26.6 \\
\hline & & & $\begin{array}{l}\text { Total no. of detained } \\
\text { youths who are } \\
\text { depressed }\end{array}$ & 1024 & 69.1 \\
\hline \multirow[t]{2}{*}{4} & \multirow[t]{2}{*}{$\begin{array}{l}\text { Kashani et al. } \\
\text { (1980) }\end{array}$} & \multirow{2}{*}{$\begin{array}{l}\text { Depression (based } \\
\text { on DSM III, } \\
1978 \text { draft) }\end{array}$} & $\begin{array}{l}\text { Youths incarcerated in } \\
\text { Juvenile Justice Centre }\end{array}$ & 100 & 18.0 \\
\hline & & & $\begin{array}{l}\text { Non-incarcerated, non- } \\
\text { delinquent youths }\end{array}$ & 50 & 4.0 \\
\hline \multirow[t]{2}{*}{5} & \multirow{2}{*}{$\begin{array}{l}\text { Ulzen and } \\
\text { Hamilton } \\
\text { (1998) }\end{array}$} & \multirow{2}{*}{$\begin{array}{l}\text { Currently } \\
\text { depressed }\end{array}$} & Incarcerated adolescents & 49 & 30.6 \\
\hline & & & $\begin{array}{l}\text { Non-incarcerated } \\
\text { adolescents }\end{array}$ & 49 & 4.1 \\
\hline \multirow[t]{2}{*}{6} & \multirow{2}{*}{$\begin{array}{l}\text { Pelissier and } \\
\text { O'Neil (2000) }\end{array}$} & \multirow{2}{*}{$\begin{array}{l}\text { Based on DSM- } \\
\text { III-R (DIS) }\end{array}$} & Male & 467 & 16.7 \\
\hline & & & Female & 142 & 32.4 \\
\hline \multirow[t]{5}{*}{7} & \multirow{5}{*}{$\begin{array}{l}\text { Boothby and } \\
\text { Durham } \\
\text { (1999) }\end{array}$} & \multirow{5}{*}{$\begin{array}{l}\text { Beck Depression } \\
\text { inventory }\end{array}$} & incarcerated prisoners: & & \\
\hline & & & a. minimum & 1494 & 43.0 \\
\hline & & & b. mild & 1494 & 30.0 \\
\hline & & & c. moderate & 1494 & 22.0 \\
\hline & & & d. severe & 1494 & 5 \\
\hline \multirow[t]{2}{*}{8} & \multirow{2}{*}{$\begin{array}{l}\text { Eyestone and } \\
\text { Howell (1994) }\end{array}$} & DSM-III-R - major & Inmates & 102 & 25.0 \\
\hline & & $\begin{array}{l}\text { DSM-III-R - not } \\
\text { full }\end{array}$ & Inmates & 102 & $>50$ \\
\hline 19 & $\begin{array}{l}\text { Chiles et al. } \\
\text { (1980) }\end{array}$ & Major depression & adolescents at entry & 120 & 23.0 \\
\hline
\end{tabular}

${ }^{a}$ Eyestone and Howell (1994) as cited in Boothby and Durham (1999). 
people may argue that prisoners should be depressed and should suffer emotionally while they are incarcerated' (p. 110). They proposed that not dealing with depression among inmates is costly to the prison system for the following reasons: first, due to close living quarters, acting out in response to depression affects not just the depressed inmate, but also the rest of the prison community; secondly, depressed inmates may engage in self-injuring behaviour, possibly to the extent of suicide, which results in high treatment costs. Overall, studies on mental health of prisoners assert that this is a population in great need of diagnosis and services (e.g. Cocozza and Skowyra, 2000; Abram et al., 2003; Grisso et al., 2005; Washburn et al., 2008).

None of these studies attempted to explain whether the higher rates of depression were due to incarceration, except Kashani et al. (1980). Among the 18 depressed delinquents in the latter study, seven developed depression during incarceration. Of these, five who were available for follow-up showed reduced symptoms of depression after release. Hence, for these five youths, depression may have been caused by incarceration. Kashani and colleagues proposed that separation from family, the stress of arrest and detention, and inability to act out while in confinement are potential reasons for onset of depression while incarcerated.

Overall, then, existing research has provided little evidence of depression induced by imprisonment, even though incarceration might be expected to lead to it. Further, there might be a dose response relationship: the harsher the punishment, the greater the sensory deprivation, then the higher the likelihood and degree of depression. Many states in the USA have, nevertheless, instituted harsher punishments on juveniles by expanding the ways in which juveniles can be sentenced to adult prisons. In Michigan, prosecutors were given substantial discretion to transfer juveniles to the criminal court or 'designate' them to be tried as adults in the juvenile court (Shook and Sarri, 2008). These changes were consistent with the 'get tough' trends of the 1980s and 1990s when almost every state enacted legislative changes easing the process of treating juveniles as adults (Shook, 2005). The result of these reforms in Michigan has been an increase in the total number of juveniles being committed to adult prisons and an increase in the proportion of youths committed for less serious offences or a probation violation (Shook and Sarri, 2008). From 1985-2004, 2240 juveniles (in Michigan, being under age 17 at the time of the offence) were committed to adult prisons (Shook and Sarri, 2008).

Of all published research on depression and incarceration, we could find only one study which compared depression among youths processed in the adult versus the juvenile systems (Washburn et al., 2008). Further, this was the only study that used multivariate analysis. Other studies used binary $t$ tests and $\chi^{2}$ tests to compare incarcerated-community youths or male-female incarcerated youths. Controlling for gender, race/ethnicity and age, Washburn et al. found no significant difference between adult and juvenile-processed youths in having any form of psychiatric disorder. These authors had, however, studied adult court 
processing and not adult imprisonment. Some of their respondents might, in the end, have received juvenile placements.

Comparisons of youths in such circumstances are not entirely straightforward, because factors which determine the nature of imprisonment may also affect mental state. In particular, depression may be related to pre-incarceration factors such as nature of behaviour, economic deprivation and family history. More serious offenders, for example, may be more depressed (Alessi et al., 1984; Odgers et al., 2007). Without controlling for nature of offence, therefore, it is impossible to make an accurate judgement of the true effect of placement type on mood. In addition, hardship generates mental stress (Lorant et al., 2007), and poorer and lesser educated individuals may go on to commit more serious crime (Bjerk, 2007; Agnew et al., 2008), in turn masking any independent effect of placement. Finally, genes, family socialisation, and the interaction between them have been found to influence criminal behaviour (e.g. Mednick and Volavka, 1980; McCord, 1991; Brennan and Mednick, 1993).

With our study, we aimed to fill a gap in the literature by studying the incarceration of juveniles in adult prisons as a factor in the occurrence of depression. We compared four different groups of youths: (1) youths incarcerated for serious offences in adult facilities; (2) youths incarcerated for serious offences in juvenile facilities; (3) youths incarcerated for less serious offences and (4) non-incarcerated and non-offending youths, allowing for possible confounders, including nature of offence, educational achievement and family and socialisation variables.

\section{Methods}

Sample and procedures

Data were from two sources. First, data on incarcerated youths who have committed very serious offenses in Michigan are from interviews conducted as part of a larger study of juveniles committed to adult prisons in Michigan. The 47 Michigan youths in adult prisons were identified by the Department of Corrections (DOC) as individuals who had been included in a larger sample of 2240 youth sentenced as juveniles to the DOC between 1985 and 2004. All of them had originally been charged as adults for offences that were committed when they were under 17 years old. The interviews were conducted in eight different prisons in Michigan. The sample of youths who remained in juvenile placements included 31 youths who were residing in five halfway houses responsible for preparing them for release from the Department of Human Services (DHS), plus an additional fourteen who were referred directly from the two state training Schools.

All DHS and DOC respondents were interviewed in 2007 or 2008. Each individual participated voluntarily and could terminate participation at any time. The interviews were conducted in closed private rooms or corners with no staff 
present. The names of those to be interviewed were identified by the state office of the two respective Departments, so as to protect the identity of the larger sample. Both Departments also gave written approval for the study.

The procedures and instruments for this study were all approved by the Behavioral Science Institution Review Board of the University of Michigan on 12 April 2006, followed by periodic reviews until the study was completed in 2009. A privacy certificate was obtained from the National Institute of Child Health and Human Development on 28 July 2006 to assure proper procedures and to protect the research staff in the event of subpoena. Special requirements had to be followed throughout because the sample being studied was incarcerated persons and the US government requires special protection for minors and persons at risk such as prisoners.

The Panel Study of Income Dynamics (PSID) provided data on the other group of incarcerated youths and the group of non-incarcerated youths. This longitudinal study followed families since 1968 and has been used widely to study youth development. In 2007, the PSID started a Transition to Adulthood (TA) sample from children of its child development supplement (CDS) who have reached 18 years old and above. In the TA sample, questions on incarceration were asked as part of understanding the places where youths lived in as they became adults. The TA is publicly available data.

For our analyses, we first compared depression rates between the four groups of youths without controlling for other variables. We then computed the odds of being depressed for the three groups with incarceration experience relative to the non-incarcerated group, using logistic regression and controlling for seriousness of offence, public assistance history, caregiver incarceration, sex, age and race/ethnicity.

\section{Variables}

\section{Depression}

The dependent variable is a binary variable where 1 indicates that the respondent was depressed, and 0 indicates that the respondent was not depressed. The variable was derived from self-reported questions from the Centre for Epidemiologic Studies-Depression Scale (CES-D; Radloff, 1977) for the Michigan data and from Kessler-6 (Kessler et al., 2002) for the PSID data. Each answer in the CES-D scale ranged from 0 to 3, so that after summing the 20 individual items, those with scores above 16 are classified as depressed. For Kessler, the range for each answer was $0-4$, so that summation resulted in those with scores above 12 defined as depression. Although the scaling is different, according to Kessler et al., the K-6 scale was designed as a shortened tool for general surveys and is derived from more diagnostic scales including the CES-D. K-6 is being used by government health surveys in the USA and Canada as well as the World Health 
Organization. The Michigan survey asked about depression in the week prior to the interview, whereas the PSID referred to the previous month. Since the PSID covers a longer period, rates should be higher for similar youths.

\section{Incarceration types}

The non-incarcerated youths in the PSID sample $(N=676)$ were used as the base group for the multivariate analysis. Dichotomous variables were created for the PSID incarcerated youths $(N=69)$, the Michigan serious offenders in juvenile facilities (DHS, $N=45$ ), and the Michigan serious offenders in adult prisons (DOC, $N=47$ ). As serious offenders are expected to receive harsher punishment than the less serious offenders, the severity of punishment is assumed to increase from the PSID to the DHS to the DOC samples.

For the PSID incarcerated youths, incarceration was indicated simply by a 'yes' answer to the question of whether the respondent had ever been in jail. This is a very broad incarceration variable. For the Michigan sample, the 45 DHS respondents and 47 DOC respondents were within 6 months of discharge, and had been arrested before age 17 .

\section{Parental incarceration}

In the Michigan data, parental incarceration data were taken from participant report; in the PSID, parental incarceration history was from multiple sources. First, caregivers were identified by matching respondents to their caregivers in the 2002 CDS, or if unavailable, the 1997 CDS. Caregivers' responses were then traced year by year from the birth year of the respondent. Incarceration was recorded as having taken place if one or more of the following was true: (a) the carer did not respond that year because she/he was in prison or jail; (b) the individual was surveyed in prison or jail or (c) the individual's answer was yes to a question in 1995 that she/he had spent time in a corrections institution.

\section{Public assistance}

An individual was rated as in receipt of this if his/her family had received public assistance, including food stamps or supplementary security income (SSI), between the year of birth and age 14 or 15 years.

\section{Person and weapon offence}

Type of offence was also a binary variable, where 1 indicates a person and/or weapon offence and 0 indicates property, drug and/or other offences. These were classified from 26 categories in the Michigan data and 25 categories in the PSID data. 


\section{Demographic variables}

The analysis also controlled for age in years, gender and ethnicity. Dummy variables were created for female gender, African-American ethnicity and those who indicated Hispanic, other or mixed race. The base demographic profile was thus white and male.

\section{Results}

\section{Bivariate analyses}

Table 2 shows the distribution of depression and the socio-demographic variables across the four study groups. More than half the Michigan youths who were in adult placements (DOC) reported depression; this group had the highest rate of depression, although not significantly higher than that of the Michigan youths incarcerated in juvenile placements (DHS). Depression rates among the more minor offenders were lower, with just $16 \%$ of the incarcerated PSID offenders showing depression. The depression rate among the community youths in the PSID was even lower at $4.9 \%$. Compared with the rates reported in Table 1 from already published research, the rate for non-incarcerated youths is comparable while the rates for the serious offenders are much higher.

\section{Multivariate analysis}

Table 3 shows that those youths who had been placed in adult incarceration had significantly higher likelihood of being depressed compared with all the other groups, after controlling for the other factors that might predicate depression. The odds of being depressed rather than not depressed for the group in adult incarceration was 64 times that of community youths [specification (1)], 22 times that of minor offenders in the PSID sample [specification (3)] and 37 times that of serious offenders in juvenile placements [specification (5)]. Moving down to a lower level of punishment, the odds ratios of depression for the DHS respondents were 10 times that of community youths [specification (1)], and not significantly different from youths in the TA sample who had committed minor offences. Finally, specification (1) also shows that the group of minor offenders had a depressed-not depressed odds ratio that was 4.6 times that of the non-offenders group. This number is significant and large, but small in comparison to the odds of depression of serious offenders in juvenile as well as adult facilities. If we confine the analysis only to male respondents [specifications (2), (4) and (6)], the qualitative results are similar, although the effect sizes differ slightly. Putting the results together, it was confirmed that there was a hierarchy of rates of depression according to severity of punishment.

Only three of the socio-economic variables were independently related to depression, and these for only some groups of respondents. Parental incarceration significantly increased the odds of depression only among the incarcerated 
Table 2: Summary statistics of variables

\begin{tabular}{|c|c|c|c|c|c|c|c|c|}
\hline & \multicolumn{2}{|c|}{$\mathrm{DOC}^{\mathrm{a}}$} & \multicolumn{2}{|c|}{$\mathrm{DHS}^{\mathrm{b}}$} & \multicolumn{2}{|c|}{$\begin{array}{l}\text { PSID- } \\
\text { incarcerated }^{c}\end{array}$} & \multicolumn{2}{|c|}{ Community } \\
\hline & $N$ & $\%$ & $N$ & $\%$ & $N$ & $\%$ & $N$ & $\%$ \\
\hline Depressed & 24 & $\begin{array}{l}51.06 \% \\
(50.53)\end{array}$ & 19 & $\begin{array}{l}42.22 \% \\
(49.95) * *\end{array}$ & 11 & $\begin{array}{c}15.94 \% \\
(36.87)^{* *}\end{array}$ & 34 & $\begin{array}{l}4.88 \% \\
(21.56)\end{array}$ \\
\hline $\begin{array}{l}\text { Received public } \\
\text { assistance growing } \\
\text { up }\end{array}$ & 23 & $\begin{array}{l}48.94 \% \\
(50.53)^{* *}\end{array}$ & 35 & $\begin{array}{l}77.78 \% \\
(42.04)\end{array}$ & 34 & $\begin{array}{l}49.28 \% \\
(50.36)^{* *}\end{array}$ & 250 & $\begin{array}{l}37.13 \% \\
(48.35)\end{array}$ \\
\hline Parental incarceration & 27 & $\begin{array}{l}57.46 \% \\
(49.98)^{* *}\end{array}$ & 44 & $\begin{array}{l}97.78 \% \\
(14.91)^{* *}\end{array}$ & 40 & $\begin{array}{c}57.97 \% \\
(23.54) * *\end{array}$ & 260 & $\begin{array}{l}38.46 \% \\
(19.25)\end{array}$ \\
\hline $\begin{array}{l}\text { Person or weapon } \\
\text { offence }\end{array}$ & 17 & $\begin{array}{l}36.17 \% \\
(48.57)^{* *}\end{array}$ & 29 & $\begin{array}{c}64.44 \% \\
(48.41)^{* *}\end{array}$ & 13 & $\begin{array}{l}18.84 \% \\
(39.39)^{* *}\end{array}$ & 8 & $\begin{array}{c}1.18 \% \\
(10.82)\end{array}$ \\
\hline Female & 2 & $\begin{array}{r}4.26 \% \\
(20.40)^{*}\end{array}$ & 9 & $\begin{array}{c}20.00 \% \\
(40.45)^{* *}\end{array}$ & 24 & $\begin{array}{l}34.78 \% \\
(47.98) * *\end{array}$ & 374 & $\begin{array}{l}55.33 \% \\
(49.75)\end{array}$ \\
\hline Age (16-29) & 11 & $\begin{array}{c}23.94 \% \\
(1.34)^{* *} \\
{[21-29]}\end{array}$ & 8 & $\begin{array}{c}18.2 \% \\
(0.99)^{* *} \\
{[16-20]}\end{array}$ & 13 & $\begin{array}{c}19.11 \% \\
(0.98)^{* *} \\
{[17-21]}\end{array}$ & 128 & $\begin{array}{c}18.90 \% \\
(1.09) \\
{[17-21]}\end{array}$ \\
\hline \multicolumn{9}{|l|}{ Race/ethnicity } \\
\hline White & 23 & $\begin{array}{l}48.94 \% \\
(50.53)\end{array}$ & 17 & $\begin{array}{l}37.78 \% \\
(49.03)\end{array}$ & 28 & $\begin{array}{l}40.58 \% \\
(49.46)\end{array}$ & 334 & $\begin{array}{l}49.41 \% \\
(50.03)\end{array}$ \\
\hline African-American & 19 & $\begin{array}{l}40.43 \% \\
(49.51)\end{array}$ & 19 & $\begin{array}{l}42.22 \% \\
(49.95)\end{array}$ & 32 & $\begin{array}{l}46.38 \% \\
(50.23)\end{array}$ & 268 & $\begin{array}{l}39.64 \% \\
(48.95)\end{array}$ \\
\hline $\begin{array}{l}\text { Hispanic or other } \\
\text { race/ethnicity }\end{array}$ & 5 & $\begin{array}{l}10.64 \% \\
(31.17)\end{array}$ & 9 & $\begin{array}{l}20.00 \% \\
(40.45)\end{array}$ & 9 & $\begin{array}{l}13.04 \% \\
(33.92)\end{array}$ & 74 & $\begin{array}{l}10.95 \% \\
(31.25)\end{array}$ \\
\hline$N$ & 47 & $100 \%$ & 45 & $100 \%$ & 69 & $100 \%$ & 676 & $100 \%$ \\
\hline
\end{tabular}

a Significant at $* 5 \%$, $* * 1 \%$ between DOC (Michigan sample of serious offenders in adult prisons) and DHS (Michigan sample of serious offenders in juvenile facilities).

${ }^{\mathrm{b}}$ Significant at $* 5 \%, * * 1 \%$ between Michigan sample and PSID sentenced sample.

'Significant at $* 5 \%$, $* * 1 \%$ between incarcerated sample (i.e. DOC, DHS and PSID incarcerated) and community non-offending youths.

(Standard deviations in parenthesis)

DOC, Department of Corrections; DHS, Department of Human Services; PSID, Panel Study of Income Dynamics.

samples, that is, those in DOC, DHS and TA. Females were more likely to be depressed, except for those in Michigan who had committed serious offences, although this result should be treated with caution as the numbers of females in the incarcerated samples were small. Finally, younger age resulted in lower odds of depression only among serious offenders or male incarcerated youths.

\section{Discussion}

Our main findings were that youths who are incarcerated in prison for serious offences are more likely to be depressed than youths committing less serious or 
Table 3: Logistic odds ratios of being depressed on incarceration type

\begin{tabular}{|c|c|c|c|c|c|c|}
\hline & \multicolumn{2}{|l|}{ Full sample } & \multicolumn{2}{|c|}{$\begin{array}{l}\text { Only incarcerated } \\
\text { youths }\end{array}$} & \multicolumn{2}{|c|}{$\begin{array}{l}\text { Only Michigan } \\
\text { sample }\end{array}$} \\
\hline & (1) & (2) & (3) & (4) & (5) & (6) \\
\hline & $\begin{array}{l}\text { Both } \\
\text { sexes }\end{array}$ & $\begin{array}{l}\text { Males } \\
\text { only }\end{array}$ & $\begin{array}{l}\text { Both } \\
\text { sexes }\end{array}$ & $\begin{array}{l}\text { Males } \\
\text { only }\end{array}$ & $\begin{array}{l}\text { Both } \\
\text { sexes }\end{array}$ & $\begin{array}{l}\text { Males } \\
\text { only }\end{array}$ \\
\hline DOC (adult) & $\begin{array}{l}64.24 \\
(48.19) * *\end{array}$ & $\begin{array}{l}98.12 \\
(98.76)^{* *}\end{array}$ & $\begin{array}{l}22.11 \\
(21.98) * *\end{array}$ & $\begin{array}{l}49.91 \\
(60.29)^{* *}\end{array}$ & $\begin{array}{l}36.92 \\
(53.59)^{*}\end{array}$ & $\begin{array}{l}30.08 \\
(44.59) *\end{array}$ \\
\hline DHS (juvenile) & $\begin{array}{l}10.04 \\
(5.99) * *\end{array}$ & $\begin{array}{l}7.78 \\
(5.89)^{* *}\end{array}$ & $\begin{array}{c}1.62 \\
(1.18)\end{array}$ & $\begin{array}{c}2.05 \\
(1.77)\end{array}$ & & \\
\hline PSID-Incarcerated & $\begin{array}{l}4.59 \\
(1.82)^{* *}\end{array}$ & $\begin{array}{l}2.82 \\
(1.77)\end{array}$ & & & & \\
\hline $\begin{array}{l}\text { Person or weapon } \\
\text { offence }\end{array}$ & $\begin{array}{c}1.00 \\
(0.38)\end{array}$ & $\begin{array}{c}0.83 \\
(0.39)\end{array}$ & $\begin{array}{c}0.94 \\
(0.39)\end{array}$ & $\begin{array}{c}0.79 \\
(0.38)\end{array}$ & $\begin{array}{c}0.83 \\
(0.40)\end{array}$ & $\begin{array}{l}0.65 \\
(0.34)\end{array}$ \\
\hline Public assistance & $\begin{array}{c}1.15 \\
(0.32)\end{array}$ & $\begin{array}{c}1.50 \\
(0.58)\end{array}$ & $\begin{array}{c}0.82 \\
(0.34)\end{array}$ & $\begin{array}{c}0.92 \\
(0.43)\end{array}$ & $\begin{array}{c}0.81 \\
(0.44)\end{array}$ & $\begin{array}{c}0.75 \\
(0.42)\end{array}$ \\
\hline $\begin{array}{l}\text { Parental } \\
\text { incarceration }\end{array}$ & $\begin{array}{c}1.83 \\
(0.82)\end{array}$ & $\begin{array}{c}2.14 \\
(1.17)\end{array}$ & $\begin{array}{l}3.42 \\
(2.05)^{*}\end{array}$ & $\begin{array}{c}3.35 \\
(2.16)\end{array}$ & $\begin{array}{l}6.44 \\
(4.94)^{*}\end{array}$ & $\begin{array}{c}6.87 \\
(5.62) *\end{array}$ \\
\hline Female & $\begin{array}{l}2.47 \\
(0.78)^{* *}\end{array}$ & & $\begin{array}{l}4.02 \\
(2.10)^{* *}\end{array}$ & & $\begin{array}{l}3.98 \\
(3.06)\end{array}$ & \\
\hline Age & $\begin{array}{c}0.84 \\
(0.10)\end{array}$ & $\begin{array}{c}0.73 \\
(0.12)\end{array}$ & $\begin{array}{c}0.75 \\
(0.13)\end{array}$ & $\begin{array}{l}0.65 \\
(0.13)^{*}\end{array}$ & $\begin{array}{l}0.65 \\
(0.14)^{*}\end{array}$ & $\begin{array}{c}0.64 \\
(0.14)^{*}\end{array}$ \\
\hline African-American & $\begin{array}{l}1.32 \\
(0.38)\end{array}$ & $\begin{array}{c}1.20 \\
(0.49)\end{array}$ & $\begin{array}{l}0.73 \\
(0.30)\end{array}$ & $\begin{array}{c}0.77 \\
(0.38)\end{array}$ & $\begin{array}{c}0.50 \\
(0.27)\end{array}$ & $\begin{array}{l}0.57 \\
(0.32)\end{array}$ \\
\hline $\begin{array}{l}\text { Hispanic or other } \\
\text { race/ethnicity }\end{array}$ & $\begin{array}{l}1.35 \\
(0.55)\end{array}$ & $\begin{array}{l}1.18 \\
(0.65)\end{array}$ & $\begin{array}{c}0.43 \\
(0.27)\end{array}$ & $\begin{array}{c}0.49 \\
(0.34)\end{array}$ & $\begin{array}{c}0.30 \\
(0.23)\end{array}$ & $\begin{array}{c}0.32 \\
(0.26)\end{array}$ \\
\hline $\mathrm{N}$ & 837 & 428 & 161 & 126 & 92 & 81 \\
\hline Log-likelihood & -217.77 & -108.64 & -86.49 & -64.53 & -56.80 & -50.05 \\
\hline
\end{tabular}

Note: Standard errors in parentheses.

* Significant at $5 \%$.

** Significant at $1 \%$.

DOC, Department of Corrections; DHS, Department of Human Services; PSID, Panel Study of Income Dynamics.

no offences. There is also an indication that incarceration of juveniles in adult prisons may elevate the risk of depression further. The bivariate comparisons showed that youths in adult prisons were not less depressed even though their offence, family and economic backgrounds were less negative than similar youths in juvenile facilities. Further, the multivariate analysis showed that the odds of depression in the adult incarcerated group was at least 20 times those of any other group after controlling for these background factors.

This finding challenges the wisdom of incarcerating youths in adult prisons. The mental health problems created or aggravated by such a policy could have 
dire consequences not only in the immediate contexts of the prison community as outlined in the beginning of this paper, but also, from a life course perspective, on the rehabilitation and re-integration of youthful ex-offenders. As summarised in a review by Fagan (2008), processing youths in adult systems provides neither general deterrence to incidence of crimes nor specific deterrence to re-offending. Instead, several researchers have articulated the negative consequences of processing juveniles as adults, including stigmatisation (Redding, 2008), learning of criminal behaviour from adult inmates (Redding, 2008), as well as increased risk of being bullied or victimised by fellow prisoners and/or staff (Ashkar \& Kenny, 2008; Redding, 2008).

So far, critics of adult incarceration of juveniles have not studied mental health outcomes, but the association with depression shown in our study suggests that the criminal justice system needs to address this seriously. Depressed individuals have been shown to have decreased task focus and productivity at work (Wang et al., 2004), increased health problems of other kinds (Sherwood et al., 2007) as well as limited ability to provide care for others (Lyons et al., 2007). Depression can be burdensome for the wider community as well as the individual, through its substantive impact on cost, both direct and indirect (Luppa et al., 2007). The economic burden of depression in Sweden, for example, was estimated to be $€ 3.5$ billion in 2005 (up from $€ 1.7$ billion in 1997) due to significant increase in sick leave and early retirement (Sobocki et al., 2007). These results imply that depressed ex-prisoners will have tremendous difficulty reintegrating to society.

At the same time that laws have become more punitive towards serious youth offenders, there have also been increased efforts at better rehabilitation and reintegration of prisoners. Whereas the current literature on depression and incarceration has called for assessment and services, the implications of the findings in this paper questions the sentencing decisions of juveniles in the first place. A hint that the adult-incarcerated sample might be undergoing very negative correctional experiences is that their backgrounds and offences were less severe than the serious offenders in juvenile placements, yet they did not have lower depression rates in the bivariate analysis and had higher odds of depression after keeping constant the background factors. Overall, the DHS group (i.e. the group of serious offenders in juvenile facilities) had the most negative background profile. A much higher proportion of them had committed more serious (person and weapons) offences and received public assistance. More staggering is that almost all of the DHS respondents had had a parent in prison. If these are predicates of depression more than incarceration, then we should expect depression rates of the DHS respondents to be highest, but the bivariate and multivariate results did not indicate so.

Differences in the profiles of the different groups of respondents constitute a limitation of the study, as they reduce comparability. As illustrated above, however, in the case of economic, offending, and parental crime backgrounds, the differences may in fact strengthen the assertion that imprisonment with 
adults contributes to depression. The gender and age profiles of respondents is another case in point. The group in adult incarceration had fewer female youths, although this is an accurate reflection of their representation in the juvenile and adult systems in Michigan. Second, youths in this group were much older. Their median age at entry into adult prison was 16 years, but most had been released from prison once or twice, had reoffended and been returned to prison. Hence, their mean age was 24 at the time of the interview. Depression rates are said to be higher among females (e.g. Pelissier and O'Neil, 2000), to decrease during early adulthood and increase later in life (e.g. Henderson et al., 1998, Mirowsky and Kim, 2007). Therefore, being older and more likely male, the adult-incarcerated respondents should have lower depression rates, but this was not so.

It was fortunate that the incompatibility of the data could be exploited to strengthen the findings. Nevertheless, the limitations of the study prevent us from concluding causation. If respondent groups were more comparable, matching techniques might help to make differences in depression levels more accurate since the differences would be between matched pairs. However, incarcerated youths are a difficult group to follow. Future research wishing to achieve greater comparability will have to expend tremendous efforts to ensure matching samples.

The findings in our study are also limited by the difficulty in truly capturing the concepts being measured. While tested and used widely, the measures of depression used by the two data sources are only survey instruments, and not diagnostic tools; furthermore, there were slight differences in the instruments and the time period for reporting covered. Offence seriousness was applied merely as a dichotomous variable, which provided only a very broad distinction between offender types. Parental incarceration and receipt of public assistance were also only proxies for intergenerational and economic effects. Therefore, there could still be unobserved confounding factors.

Further research could also investigate directly the correctional experiences of adult versus juvenile inmates. In another study, we compared correctional service experience of the adult and juvenile Michigan samples ( $\mathrm{Ng}$ et al., unpublish data). The youths in juvenile placements were found to receive more counselling, more medical attention and rate staff quality more highly. There were, however, no differences in work and education programming. Inferior services and other environmental conditions in adult prisons might trigger or worsen depression, and more research on correctional services would help to understand the mental health effects of incarceration.

Results from the other variables in this analysis might also deserve further analysis. First, females were in general more likely to be depressed. This is consistent with existing literature (Pelissier and O'Neil, 2000; Domalanta et al., 2003). However, among the sample of serious offenders, the significant difference between males and females disappeared. Might gender-based manifestation of depression differ for chronic offenders? Might the severe punishment have 
something to do with it? What do these mean for treatment of male and female prisoners? Second, there is little research on the intergenerational effects of having ex-convict parents, and the strong results here implies the importance of intergenerational interventions targeted at parents in order to forestall effects to children. More research is needed to understand intergenerational effects and effective interventions.

Despite the above limitations, for the lack of any other study considering the various co-morbid and predicate factors of depression, the strong correlation we found between incarceration type and depression is telling. In addition, exploitation of similar variables in different data sets offered a rare opportunity to pool data and compare different populations. Overall, this paper has shown the vulnerability of incarcerated youths. While they should be punished for crimes committed, the repercussions of punishment in the form of damage to mental health could have long-term consequences that in the end translate into burdens for the society.

\section{Acknowledgements}

This research was supported by funding from the W. K. Kellogg Foundation (\#007494) and the National University of Singapore Faculty Research Fund (R-134-000-056-112/133).

\section{References}

Abram KM, Teplin LA, McClelland GM, Dulcan MK (2003) Comorbid psychiatric disorders in youth in juvenile detention. Archives of General Psychiatry 60: 1097-1108.

Agnew R, Matthews SK, Bucher J, Welcher, AN, Keyes C (2008) Socioeconomic status, economic problems and delinquency. Youth and Society 40: 159-181.

Alessi NE, McManus M, Grapetine WL, Brickman A (1984) The characterization of depressive disorders in serious juvenile offenders. Journal of Affective Disorders 6: 9-17.

Ashkar PJ, Kenny DT (2008) Views from the inside: Young offenders' subjective experiences of incarceration. International Journal of Offender Therapy and Comparative Criminology 52: 584-597.

Bjerk D (2007) Measuring the relationship between youth criminal participation and household economic resources. Journal of Quantitative Criminology 23: 23-29.

Boothby JL, Durham TW (1999) Screening for depression in prisoners using the Beck depression inventory. Criminal Justice and Behavior 26: 107-124.

Brennan PA, Mednick SA (1993) Genetic perspectives on crime. Acta Psychiatrica Scandinavica 370: 19-26.

Chiles JA, Miller ML, Cox GB (1980) Depression in an adolescent delinquent population. Archives of General Psychiatry 37: 1179-1184.

Cocozza JJ, Skowyra KR (2000) Youth with mental health disorders: Issues and emerging responses. Juvenile Justice Journal 7: 3-13.

Domalanta DD, Risser WL, Roberts RE, Risser JM (2003) Prevalence of depression and other psychiatric disorders among incarcerated youths. Journal of American Academy of Child and Adolescent Psychiatry 42: 477-484. 
Fagan J (2008) Juvenile crime and criminal justice: Resolving border disputes. The Future of Children 18: 81-118.

Grisso T, Vincent G, Seagrave D (2005) Mental Health Screening and Assessment in Juvenile Justice. New York: Guilford Press.

Henderson AS, Jorm AF, Korten AE, Jacomb P, Christensen H, Rodgers B (1998) Symptoms of depression and anxiety during adult life: Evidence for a decline in prevalence with age. Psychological Medicine 28: 1321-1328.

Kashani JH, Manning GW, McKnew DH, Cytryn L, Simonds JF, Wooderson PC (1980) Depression among incarcerated delinquents. Psychiatry Research 3: 185-191.

Kessler RC, Andrews G, Colpe LJ, Hirippi E, Mroczek DK, Normand S-T, Walters EE, Zaslavsky AM (2002) Short screening scales to monitor population prevalence and trends in non-specific psychological distress. Psychological Medicine 32: 959-976.

Lorant V, Croux C, Weich S, Deliège D, Mackenbach J, Ansseau M (2007) Depression and socioeconomic risk factors: 7-year longitudinal population study. The British Journal of Psychiatry 190: 293-298.

Luppa M, Heinrich S, Angermeyer MC, König HH, Riedel-Heller SG (2007) Cost-of-illness studies of depression: A systematic review. Journal of Affective Disorders 98: 29-43.

Lyons KS, Sayer AG, Archbold PG, Hornbrook MC, Stewart BJ (2007) The enduring and contextual effects of physical health and depression on care-dyad mutuality. Research in Nursing and Health 30: 84-98.

McCord J (1991) Family relationships, juvenile delinquency, and adult criminality. Criminology 29: 397-417.

Mednick SA, Volavka J (1980) Biology and crime. Crime and Justice 2: 85-158.

Mirowsky J, Kim J. (2007) Graphing age trajectories: Vector graphs, synthetic and virtual cohort projections, and cross-sectional profiles of depression. Sociological Methods $\mathcal{E}$ Research 35(4): 497-541.

Odgers CL, Moretti MM, Burnette ML, Chauhan P, Waite D, Reppucci ND (2007) A latent variable modeling approach to identifying subtypes of serious and violent female juvenile offenders. Aggressive Behavior 33: 339-352.

Pelissier BMM, O'Neil JA (2000) Antisocial personality and depression among incarcerated drug treatment participants. Journal of Substance Abuse 11: 379-393.

Radloff LS (1977) The CES-D scale: A self-report depression scale for research in the general population. Applied Psychological Measurement 1: 385-401.

Redding RE (2008) Juvenile transfer laws: An effective deterrent to delinquency. Juvenile Justice Bulletin (August): 1-12.

Sherwood A, Blumenthal JA, Trivedi R, Johnson KS, O'Connor CM, Adams Jr, KF, Dupree CS, Waugh RA, Bensimhon DR, Gaulden L, Christenson RH, Koch G, Hinderliter AL (2007). Relationship of depression to death or hospitalization in patients with heart failure. Archives of Internal Medicine 167: 367-373.

Shook JJ (2005) Contesting childhood in the US justice system: The transfer of juveniles to the adult criminal court. Childhood 12: 4610-478.

Shook JJ, Sarri RC (2008) Trends in the commitment of juveniles to adult prisons: Toward an increased willingness to treat juveniles as adults? The Wayne Law Review 54: 1725-1765.

Sobocki P, Lekander I, Borgström F, Ström O, Runeson B (2007) The economic burden of depression in Sweden from 1997 to 2005. European Psychiatry 22: 146-152.

Ulzen TP, Hamilton H (1998) The nature and characteristics of psychiatric comorbidity in incarcerated adolescents. Canadian Journal of Psychiatry 43: 57-63.

Wang PS, Beck AL, Berglund P, McKenas DK, Pronk NP, Simon GE, Kessler RC (2004) Effects of major depression on moment-in-time work performance. The American Journal of Psychiatry 161: 1885-1891. 
Washburn JJ, Teplin LA, Voss LS, Simon CD, Abram KM, McClelland GM (2008) Psychiatric disorders among detained youths: A comparison of youths processed in juvenile court and adult criminal court. Psychiatric Services 59: 965-973.

Wasserman GA, Ko SJ, McReynolds LS (2004) Assessing the mental health status of youth in juvenile justice settings. Juvenile Justice Bulletin (August): 1-7.

Address correspondence to: Irene Y.H. Ng, Department of Social Work, National University of Singapore, AS3 Level 4, 3 Arts Link, Singapore 117570, Singapore. Email: swknyhi@nus.edu.sg 